\title{
Applying multi-criteria analysis for preliminary assessment of the properties of alginate immobilized Myriophyllum spicatum in lake water samples
}

\author{
Jelena V. Milojković a, *, 1 , Jelena B. Popović-Djordjević ${ }^{\text {b, }}{ }^{\text {, }}$ Lato L. Pezo ${ }^{\text {c }}$, Ilija D. Brčeski ${ }^{\text {d }}$, \\ Aleksandar Ž. Kostić ${ }^{\text {b }}$, Vladan D. Milošević a, Mirjana D. Stojanović a \\ a Institute for Technology of Nuclear and Other Mineral Raw Materials, 86 Franchet d'Esperey St., Belgrade, Serbia \\ ${ }^{\mathrm{b}}$ University of Belgrade, Faculty of Agriculture, Department of Chemistry and Biochemistry, Nemanjina 6, 11080 Belgrade, Serbia \\ ${ }^{c}$ Institute of General and Physical Chemistry, University of Belgrade, Studentski Trg 12 - 16, 11000 Belgrade, Serbia \\ d University of Belgrade, Faculty of Chemistry, Studentski trg 12-16, 11000 Belgrade, Serbia
}

\section{A R T I C L E I N F O}

\section{Article history:}

Received 13 December 2017

Received in revised form

9 May 2018

Accepted 10 May 2018

Available online 11 May 2018

\section{Keywords:}

Lake water samples

Immobilized aquatic weed

Biosorption

Water quality

Multi-criteria analysis

\begin{abstract}
A B S T R A C T
The preliminary assessment of the properties of alginate immobilized aquatic weed Myriophyllum spicatum beads-MsAlg in a multi-element system of nine Serbian lakes water samples was done. Herein, the results obtained in the biosorption experiment with MsAlg contents of twenty-two elements analysed by inductively coupled plasma-optical emission spectrometry, biosorption capacity, element removal efficiency, total hardness (TH) and quality index of water (WQI) are presented. Scanning electron microscopy with energy dispersive X-ray spectroscopy was used for the characterization of M. spicatum and its beads. The study showed that aluminium, magnesium and strontium were adsorbed by MsAlg in the water samples from all examined lakes; barium and iron in the water samples from six lakes. The overall average efficiency of MsAlg in biosorption of elements was in the following order: $\mathrm{Al}>\mathrm{Ba}>\mathrm{Sr}>\mathrm{Fe}>\mathrm{Mg}$ (58.6, 51.7, 48.2, 23.9 and 17.7\%, respectively). The increase of TH and WQI values after the biosorption was noticed in all studied lake water samples. The most significant correlations for $\mathrm{pH}$ were regarding the contents of $\mathrm{B}, \mathrm{Mg}$ and $\mathrm{Ca}$, whereas WQI was highly correlated to the contents of $\mathrm{B}$ and $\mathrm{Mg}$, and $\mathrm{pH}$. The complexity of the obtained data was explained by Cluster Analysis and Principal Component Analysis, which showed good discrimination capabilities between the water samples taken from different locations. Considering that the invasive M. spicatum is natural, widespread and that its immobilization is cheap and eco-friendly, presented findings could be helpful in further assessment of MsAlg beads for its potential use as biofilter.
\end{abstract}

(c) 2018 Elsevier Ltd. All rights reserved.

\section{Introduction}

Water is the basis for a healthy life and is directly related to human survival. So, the awareness of the limited amount of unpolluted water available to mankind is on the rise. Anthropogenic disturbances of ambient groundwater flows (ex., by agricultural, mining and industrial activities, urbanization, and/or climate change) which could cause production of different contaminants (highly toxic heavy metals or non-toxic bio-degradable materials)

\footnotetext{
* Corresponding author. Institute for Technology of Nuclear and Other Mineral Raw Materials, 86 Franchet d'Esperey St., Belgrade, Serbia.

E-mail address: j.milojkovic@itnms.ac.rs (J.V. Milojković).

1 These authors contributed equally to this work.
}

greatly affect the quality of water (Kostić et al., 2016; Azizian et al., 2017). Special attention should be paid to surface water quality, as the understanding of raw water quality is equally important to humans as well as to aquatic life (Şener et al., 2017).

Various techniques (precipitation, ion-exchange, adsorption, and reverse osmosis etc.) have been utilized for the toxic elements removal from aquatic environment (Cheng et al., 2017). The methodology of the biosorption study which is based on the interdisciplinary approach of chemists, (micro)biologists and (process)engineers has emerged as an economically feasible alternative for the removal of toxic elements utilizing naturally abundant, waste biomass and immobilized biomass in a polymer matrix (Kratochvil and Volesky, 1998; Volesky, 2007).

Eurasian water milfoil Myriophyllum spicatum, grows on five 
continents and may be native and invasive plant species (Couch and Nelson, 1985). This aquatic weed can be found in various aquatic habitats such as: lakes, rivers, reservoirs, freshwater and brackish estuaries (Aiken et al., 1979). M. spicatum reproduces primarily by vegetative fragmentation and forms dense beds. Therefore, milfoil becomes a human nuisance and has adverse effects on native aquatic vegetation, decreases dissolved oxygen, reduces open areas along lake shores, creates habitats for disease-carrying insects, reduces water flow, irrigation ditches, canals, farm ponds, and irrigation equipment by clogging (Bates et al., 1985). Methods for growth control of this weed are: physical (harvesting), chemical and biological (Milojković et al., 2014). In accordance with requirements of sustainability, managing and processing of aquaticwaste need to be integrated and organized (Milojković et al., 2016a). Alginate as seaweed (brown algae) extract is a frequently used polymer for immobilization and microencapsulation technique (Taqieddin and Amiji, 2004). Calcium alginate beads are widely used as a supporting material in studies of biosorbent immobilization. They exhibit good biocompatibility and are easy to prepare. In addition, they have low prices and are easily available (Zhou et al., 2010). The alginate-immobilized Myriophyllum spicatum beads (Ms:Alginate 5:1) in biosorption tests of $\mathrm{Pb}(\mathrm{II})$ under laboratory conditions were recently described. Those M. spicatum beads achieved $\mathrm{Pb}$ (II) uptake of $200 \mathrm{mg} / \mathrm{g}$ (Milojković et al., 2016a).

Cluster analysis (CA) was performed to classify the samples of water. In this study, complete linkage was used and City-block (Manhattan) distance was calculated in cluster analysis. Principal Component Analysis (PCA) is a mathematical procedure used widely in chemometric data analysis, representing a multivariate technique (Tan and Lu, 2015; Mezzelani et al., 2016). PCA was performed by Eigenvalue decomposition of the correlation matrix of the obtained data (Olenycz et al., 2015; Touahri et al., 2016). PCA was applied to analyse the similarities of the samples, and also the trace element content (Pain-Devin et al., 2014; Bolotov et al., 2015; Robinson et al., 2017). The main idea for using PCA was the reduction of the number of variables, called the principal components (PCs). PCs explain the major variations within the data to make the components more interpretable (Lehtonen et al., 2016). The first two PCs were extracted and utilized in two dimensional bivariate plots; loadings were considered to evaluate correlations between variables. Prior to PCA and CA, the data sets were examined for outliers. Data were analysed by Statistica software (Data Analysis Software System, v.10.0, StatSoft, Inc, Tulsa, OK, USA).

Further investigations of Myriophyllum spicatum beads as a biosorbent are presented in this study with the aim to assess the performance of immobilized M. spicatum with alginate-MsAlg in a real system. For this purpose, we used water from nine accumulations: Bovan, Vlasina, Prvonek, Garaši, Ćelije, Vrutci, Sava, Gruža and Srebrno, which are located in the regions: Šumadija, Western Serbia, South and East Serbia. In this preliminary biosorption study with MsAlg beads in the multi-element system of lake water, biosorption capacity $(q)$, element removal efficiency $(R)$, total hardness (TH) and the quality index (WQI) of water before and after biosorption were determined. The multivariate composition of the examined samples was evaluated, and PCA and CA were applied to characterize and discriminate examined water samples. To the best of our knowledge, the current study presents the first data on the characterization and output of MsAlg in a real system (lake water).

\section{Materials and methods}

The studied lakes (Fig. 1) are located in the area of about $88361 \mathrm{~km}^{2}$ (US Demographic yearbook, 2012). Geographical coordinates and elevations of the lakes are: Vlasina $-42^{\circ} 42^{\prime} \mathrm{N} / 22^{\circ} 20^{\prime}$

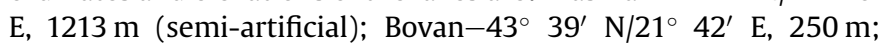

Prvonek-42 $30^{\prime} \mathrm{N} / 22^{\circ} 05^{\prime} \mathrm{E}, 580 \mathrm{~m}$; Garaši-44 $14^{\circ} \mathrm{N} / 20^{\circ} 28^{\prime} \mathrm{E}$, $268 \mathrm{~m}$; Ćelije $-43^{\circ} 24^{\prime} \mathrm{N} / 21^{\circ} 10^{\prime} \mathrm{E}, 426 \mathrm{~m}$; Vrutci-43 $43^{\circ} \mathrm{N}$ N $/ 19^{\circ} 41^{\prime}$

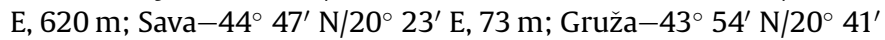
E, $267 \mathrm{~m}$; Srebrno-44 $45^{\prime} \mathrm{N} / 21^{\circ} 25^{\prime} \mathrm{E}, 70 \mathrm{~m}$ (artificial lakes). All the lakes belong to freshwater lakes. Hydrological data and intended use of the lakes are presented in Table S1 (Supplementary material). Lakes Sava and Srebrno are parts of the biggest rivers in Serbia; Srebrno (located near Veliko Gradište) was formed as an oxbow lake on the right bank of the Danube, whilst Sava (in Belgrade city) was formed from the right inlet of the Sava river by building two damns. These lakes are with the lowest surface elevation amongst studied lakes and are predominantly used for recreation. Lakes Bovan, Vlasina, Prvonek, Vrutci, Gruža, Ćelije and Garaši were built for water supply purpose, and for such reason they play a fundamental role in local society as sources of drinking water. Moreover, there are additional uses of lakes for energy supply (Vlasina), flood defense (Bovan and Ćelije) and fishing (Garaši) (Anonymous, 1986, 2001). In addition, lakes Sava, Vlasina, Gruža and Srebrno are natural aquatic surroundings for Myriophyllum spicatum.

\subsection{Preparation of Alginate-M. spicatum beads (MsAlg)}

The aquatic weed M. spicatum used for the preparation of beads is from Sava Lake where it is regularly harvested with underwater mower by the public company "Ada Ciganlija", Belgrade Serbia. Since this lake area is intended for recreation and water supply the growth and spread of this water weed must be controlled. The daily amount of harvested biomass is about $30-32 \mathrm{~m}^{3}$. Fresh plant material was first washed with tap water and then 3 times with distilled water. After washing M. spicatum was dried at $35^{\circ} \mathrm{C}$. Dried plant was milled and sieved to particles $<0.2 \mathrm{~mm}$. Alginic acid sodium salt from brown algae-low viscosity was used (A1112, SigmaAldrich, St. Louis, MO, USA). M. spicatum beads were made according to the method Yan and Viraraghavan (2001). Dissolving Naalginate in distilled water a $2 \%$ polymer solution was made. After homogenization a certain amount of biomass powder $(4 \mathrm{~g}$ in $100 \mathrm{ml}$ ) was added (Ms:Alginate 2:1). This slurry was then dispersed dropwise into a $0.1 \mathrm{M}$ calcium chloride solution using a syringe. Therefore, soluble sodium alginate was transformed to solid calcium alginate beads. Having stayed for $24 \mathrm{~h}$ in $2 \%$ calcium chloride solution, beads were hardened. Those that floated on the surface were unsuitable and discarded. Then the beads were placed into the conical flasks with deionised water and mixed for $30 \mathrm{~min}$. This washing process was repeated 5 times. Beads were dried at room temperature to constant weight and then used for experiments.

\subsection{Surface microstructures of MsAlg}

Dried M. spicatum and MsAlg samples coated with gold were examined on Scanning Electron Microscopy (SEM) instrument (JEOL JSM - 6610LV SEM model). Some statistical quantities were obtained by analysing the SEM figures in Gwyddion program (http://gwyddion.net/documentation/user-guide-en/statisticalanalysis.html), including a few basic properties of the height value distribution, such as the mean value and median of $M$. spicatum pores.

\subsection{Biosorption tests}

The biosorption experiments were performed with samples taken from nine freshwater lakes. Samples were collected following ISO 5667-14 standard during autumn of 2016. For each lake, samples were collected in sterile bottles from three sampling points, and mixed together to make a composite sample before being used 


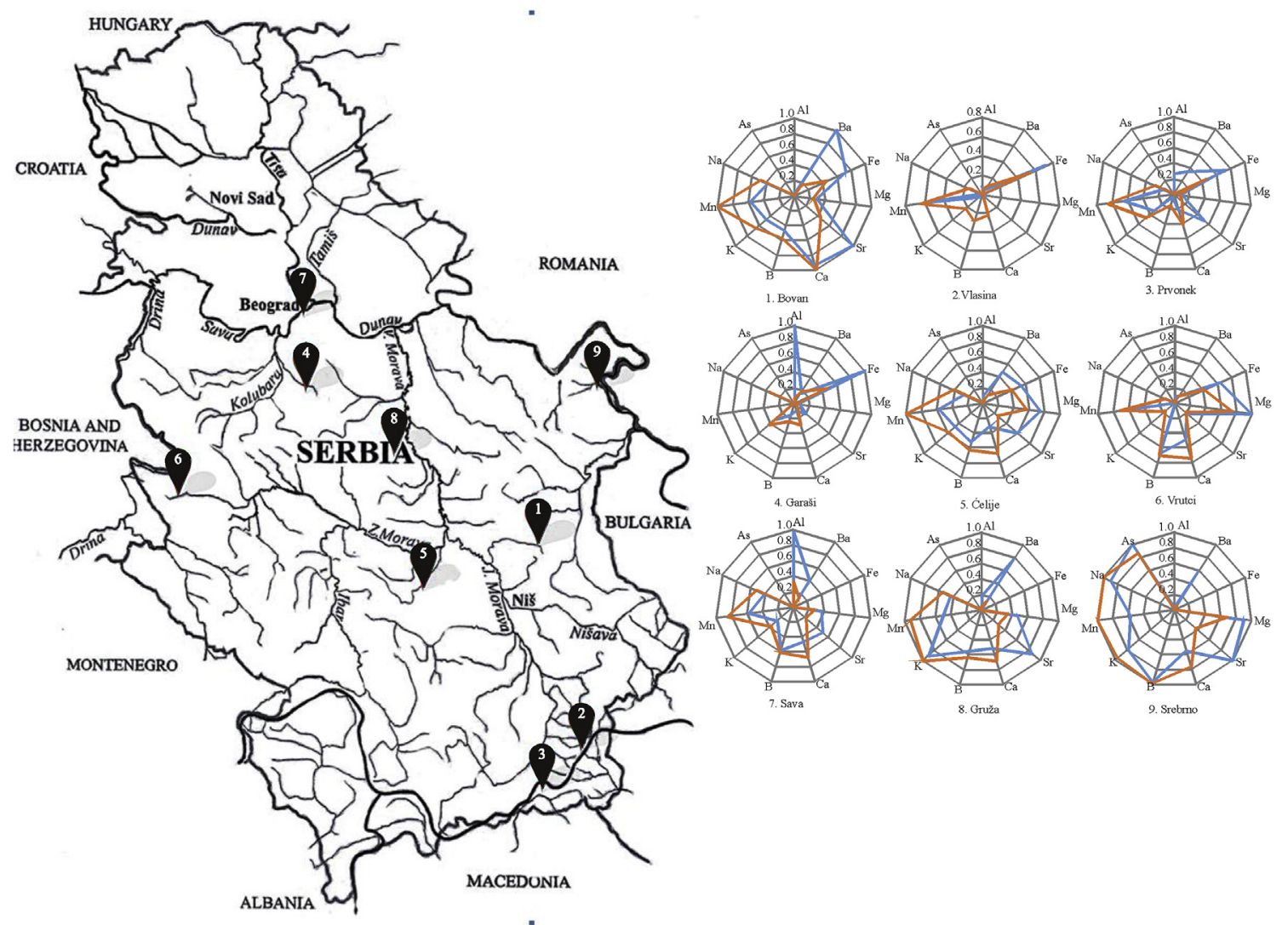

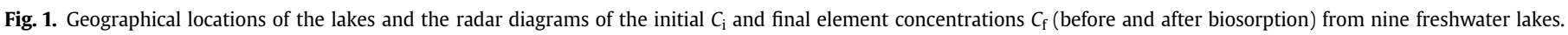

for further experimental work. Filtration of water samples was done. Subsequently, bottles with composite water samples were immediately placed in an icebox at a temperature of $4{ }^{\circ} \mathrm{C}$, and transported to the laboratory for the following analysis on the same day of sampling. Analytical technique inductively coupled plasma-optical emission spectrometry (ICP-OES) was used for determination of twenty-two elements (ICP-OES Spectroblue equipped with Spectro Smart Analyzer data processing software-SPECTRO Analytical Instruments GmbH, Germany). US EPA (Method 200.7) was applied (1994). Method performance data are given in Table S2 (Supplementary material).

Usually in biosorption experiments with fresh tissues of $M$. spicatum, the amount of applied fresh tissues is $2 \mathrm{~g} / \mathrm{L}$ calculated on dry weight. According to that, the same amount of biosorbent MsAlg was used. Beads were inserted in the samples of lake water $(50 \mathrm{ml})$ in glass erlenmeyers $(100 \mathrm{ml})$. The flasks were stirred at $200 \mathrm{rpm}$ in a Heidolphunimax 1010 orbital shaker at room temperature $\left(25^{\circ} \mathrm{C}\right)$. All sorption experiments were performed in three replications. Initial and final (after specified contact time) $\mathrm{pH}$ values of the mixtures were measured (by a precise $\mathrm{pH}$ meter Sension MM340). Contact time was $24 \mathrm{~h}$.

Biosorption capacity was determined from the expression:

$q=\frac{V\left(C_{i}-C_{f}\right)}{m}$

where biosorption capacity $q$ is the amount of various elements removed by investigated biosorbent at any time $(\mathrm{mg} / \mathrm{g}), V$ is the volume of solution (L), $C_{\mathrm{i}}$ and $C_{\mathrm{f}}$ are the initial and the final element concentrations $(\mathrm{mg} / \mathrm{L})$, respectively and $m$ is the mass of the biosorbent MsAlg (g). 2):

Element removal efficiency $(R)$ was calculated from equation

$R=\frac{C_{i}-C_{f}}{C_{i}} \cdot 100$

Total Hardness $(\mathrm{TH})$, before and after biosorption process, was calculated (Aquion, 2016) as follows:

$\mathrm{TH} \approx[\mathrm{Ca}]+[\mathrm{Mg}]$

$\mathrm{TH}$ in ${ }^{\circ} \mathrm{d}=0.1339 \times[\mathrm{Ca}$ in $\mathrm{mg} / \mathrm{L}]+0.2307 \times[\mathrm{Mg}$ in $\mathrm{mg} / \mathrm{L}]$

The water quality index (WQI) was calculated, according to equation (5):

$W Q I=\frac{\sum_{i=1}^{n} W_{i} \cdot C_{i}}{n}$

Where: $C$ is element concentration, $W$-weight coefficient, i-element number, $n$-number of elements (Chang et al., 2001; Zhaoyong et al., 2015).

\subsection{Data analysis}

Cluster analysis (CA) was performed to classify the samples of water. In this study, complete linkage was used and City-block (Manhattan) distance was calculated in cluster analysis. Principal Component Analysis (PCA) is a mathematical procedure used widely in chemometric data analysis, representing a multivariate technique (Tan and Lu, 2015; Mezzelani et al., 2016). PCA was performed by Eigenvalue decomposition of the correlation matrix 
of the obtained data (Olenycz et al., 2015; Touahri et al., 2016; Lehtonen et al., 2016). PCA was applied to analyse the similarities of the samples, and also the trace element content (Pain-Devin et al., 2014; Bolotov et al., 2015; Robinson et al., 2017). The first three principal components (PCs) were extracted and utilized in two dimensional bivariate plots; loadings were considered to evaluate correlations between variables. Data were analysed by Statistica software (Data Analysis Software System, v.10.0, StatSoft, Inc, Tulsa, OK, USA).

\section{Results and discussion}

\subsection{SEM-EDX analysis}

Scanning Electron Microscopy shows the surface texture and porosity of Myriophyllum spicatum and MsAlg (Fig. 2). White parts that can be seen on micrographs may be from the presence of calcium in the samples (Dibdiakova et al., 2015). The observed pore sizes varied between 0.077 and $0.563 \mu \mathrm{m}$, while the average and the median values were $0.316 \mu \mathrm{m}$ and $0.324 \mu \mathrm{m}$. The root means square (RMS) value was calculated to explain the height irregularities within each pore (this value is computed from SEM data variance). The variations in the height of the $M$. spicatum pores were $0.121 \mu \mathrm{m}$. Pore-wise RMS value was determined for each pore (as a contiguous part of the inserted mask) separately, and the variance was calculated from these values. Similar to RMS, the variations in height of each pore were $0.120 \mu \mathrm{m}$. The skewness value was also calculated, as the measure of symmetry, and the calculated value $(0.073)$ shows a symmetrical distribution of pore sizes. Kurtosis value was measured as comparison to normal distribution, and the evaluated value $(-1.008)$ showed a good fit for normal distribution. The surface area was computed by simple triangulation of each pore observed in SEM figure. The surface area for M. spicatum pore was $0.001 \mathrm{~mm}^{2}$. The observed pore sizes for biosorbent MsAlg varied between 0 and $0.796 \mu \mathrm{m}$, while the average and the median values were $0.225 \mu \mathrm{m}$ and $0.176 \mu \mathrm{m}$. The RMS value was $0.177 \mu \mathrm{m}$. The variation in height of each pore was $0.150 \mu \mathrm{m}$. The skewness value was 0.836 , while Kurtosis value was -0.232 . The surface area was $0.001 \mathrm{~mm}^{2}$.
The surface of samples M. spicatum and MsAlg was tested for the contents of sixteen elements. Elements $\mathrm{N}, \mathrm{F}, \mathrm{Fe}, \mathrm{Pb}$ were not detected by EDX analyses on both samples. Also, on the surface of MgAlg, Na, P, Cl, K, Cu were not identified. Amounts of detected elements are presented in Tables within Fig. 2c) and d). Gold was noticed because of sample preparation. Calcium was present more than four times in MsAlg than in aquatic weed due to the process of gelation with $\mathrm{CaCl}_{2}$.

Identified composition of elements by this instrumental technique was also confirmed by chemical composition of $M$. spicatum and calcium has the largest amount 5\% (Milojković et al., 2014). Large proportion of calcium originates from the water environment in which this aquatic weed lives. For the duration of the process of photosynthesis, submerged plants are provided, not only with free $\mathrm{CO}_{2}$, but also with one from aqueous solution of $\mathrm{Ca}\left(\mathrm{HCO}_{3}\right)_{2}$. This leads to the deposition of insoluble $\mathrm{CaCO}_{3}$ and its accumulation on the surface of leaves of submerged plants (Stevanović and Janković, 2001). The precipitation of calcite in natural waters can be shown by the reaction:

$$
\mathrm{Ca}^{2+}+2 \mathrm{HCO}_{3}^{-} \rightleftharpoons \mathrm{CaCO}_{3} \downarrow+\mathrm{CO}_{2} \uparrow+\mathrm{H}_{2} \mathrm{O}
$$

The moderate level of alkalinity ( $\mathrm{pH}$ ranging from 8.2 to 8.8 ) in Sava Lake water favours the formation of calcium carbonate (Milojković et al., 2016b).

\subsection{Element content and biosorption process in lake water samples}

US EPA has prescribed National Primary Drinking water regulations with public health goal and public health secondary drinking water standards. Chemicals of health significance are described by World Health Organization guidelines (WHO) for drinking water quality in the third edition (2008) and the fourth edition (2011). WHO has also recommended other water quality parameters.

Contents of $\mathrm{Al}, \mathrm{As}, \mathrm{B}, \mathrm{Ba}, \mathrm{Ca}, \mathrm{Cd}, \mathrm{Co}, \mathrm{Cr}, \mathrm{Cu}, \mathrm{Fe}, \mathrm{K}, \mathrm{Li}, \mathrm{Mg}, \mathrm{Mn}, \mathrm{Na}$, $\mathrm{Ni}, \mathrm{Pb}, \mathrm{Sb}, \mathrm{Se}, \mathrm{Sr}, \mathrm{V}$ and $\mathrm{Zn}$ were examined in the water samples from studied lakes. Among the examined elements, the priority pollutants such as $\mathrm{Cd}, \mathrm{Cr}, \mathrm{Cu}, \mathrm{Ni}, \mathrm{Pb}, \mathrm{Se}$ and $\mathrm{Zn}$, as well as $\mathrm{Co}, \mathrm{Li}, \mathrm{Sb}$ and $\mathrm{V}$

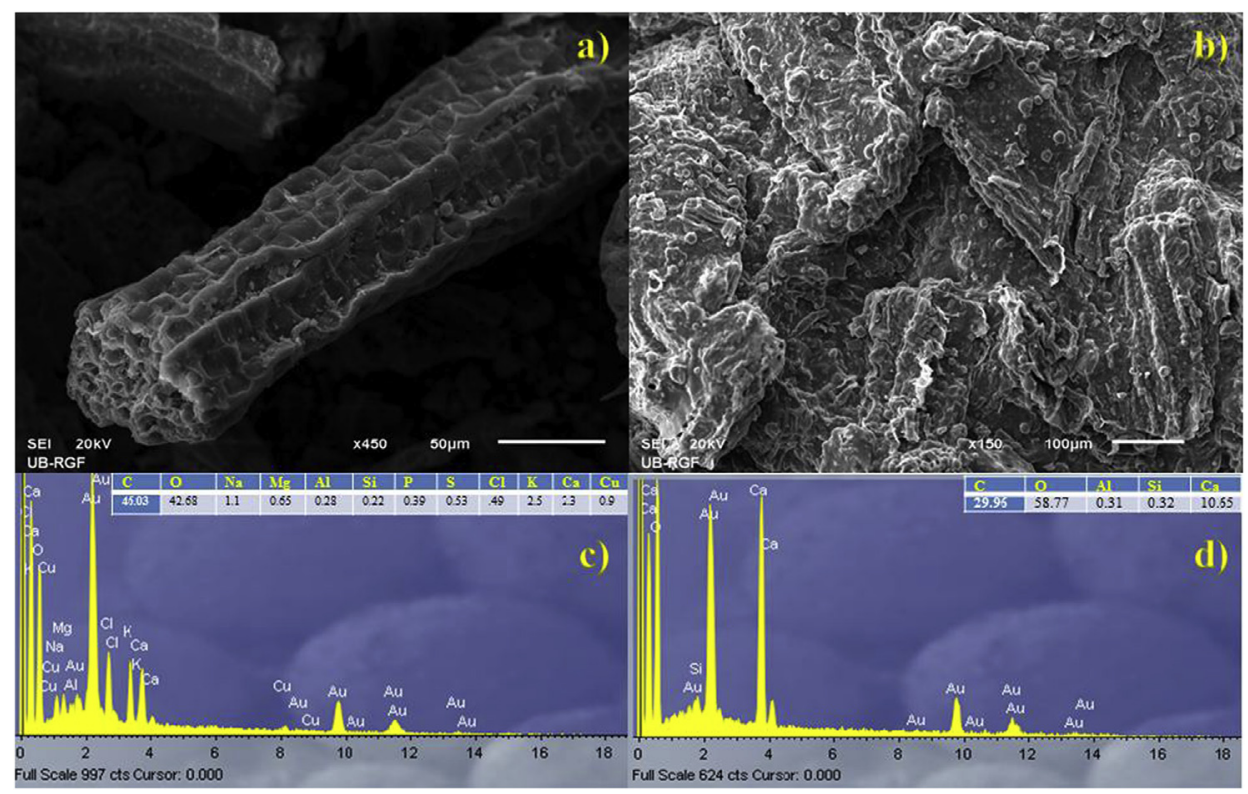

Fig. 2. SEM micrographs of a) M. spicatum b) MsAlg c) EDX analysis of M. spicatum d) EDX analysis of MsAlg. 
were below the limit of detection (LOD) in all water samples. The contents of $\mathrm{Ca}, \mathrm{K}, \mathrm{Mg}$ and $\mathrm{Na}$ were in the range 8.87-45.44, $0.64-3.14,1.71-23.81$ and $1.96-16.22 \mathrm{mg} / \mathrm{L}$, respectively. Concentrations of detected microelements were in the following ranges: $\mathrm{Al}$ $5.00-120.00 \mu \mathrm{g} / \mathrm{L}, \quad$ B $13.00-50.00 \mu \mathrm{g} / \mathrm{L}, \quad B a \quad 6.00-42.00 \mu \mathrm{g} / \mathrm{L}, \quad F e$ $6.00-11.00 \mu \mathrm{g} / \mathrm{L}, \mathrm{Mn} 7.00-9.00 \mu \mathrm{g} / \mathrm{L}$ and $\mathrm{Sr} 21.00-170.00 \mu \mathrm{g} / \mathrm{L}$. Arsenic was detected only in Srebrno lake in the concentration of $7.00 \mu \mathrm{g} / \mathrm{L}$.

Increased amount of arsenic was detected in Srebrno lake water sample (in the concentration $7.00 \mu \mathrm{g} / \mathrm{L}$ ). According to US EPA (2016a) Public Health Goal for this element concentration should be zero. After application of MsAlg, concentration of arsenic decreased to $6.00 \mu \mathrm{g} / \mathrm{L}$. Secondary Drinking Water Standards for the amount of aluminium suggested by US EPA (2016b) $(0.05-0.2 \mathrm{mg}$ / $\mathrm{L})$ and WHO $(0.1 \mathrm{mg} / \mathrm{L})$ was exceeded in samples from lakes Garaši and Sava. After biosorption aluminium content diminished, according to both standards, which approved the utilization of applied biosorption material.

Based on the obtained results, it can be noticed that the concentrations of elements in all studied lakes are within the limit values set by national and European Union (EU) regulations (EPA Ireland, 2001; Official Gazette of Serbia, 2014) (see Table S3, Supplementary material). In terms of chemical quality, water in all studied lakes was within the first category. After the treatment by appropriate methods for water purification this water may be used for drinking water supply (Official Gazette of Serbia, 2014).

Human utilization of biomass or biogenic materials as feedstock isn't new; however at this time there is a renewed interest in efficient exploitation of organic inevitable wastes, in order to decrease eco-footprint and get further stock resources that are renewable (Mohan et al., 2016). The biosorption study showed that $\mathrm{Al}, \mathrm{Fe}, \mathrm{Mg}, \mathrm{Sr}, \mathrm{Ba}$ and As were absorbed by MsAlg; aluminium, magnesium and strontium in the samples from all studied lakes; barium and iron in the samples from six lakes. Arsenic was absorbed in the water sample from Srebrno lake (the only sample where it was detected).

Based on the results of biosorption, radar diagrams have been plotted and they are presented in Fig. 1. Biosorption capacities $(q)$ of MsAlg in lake water samples are presented in Fig. 3. In lakes with higher contents of certain elements such as strontium and aluminium, the highest biosorption capacity has been achieved.

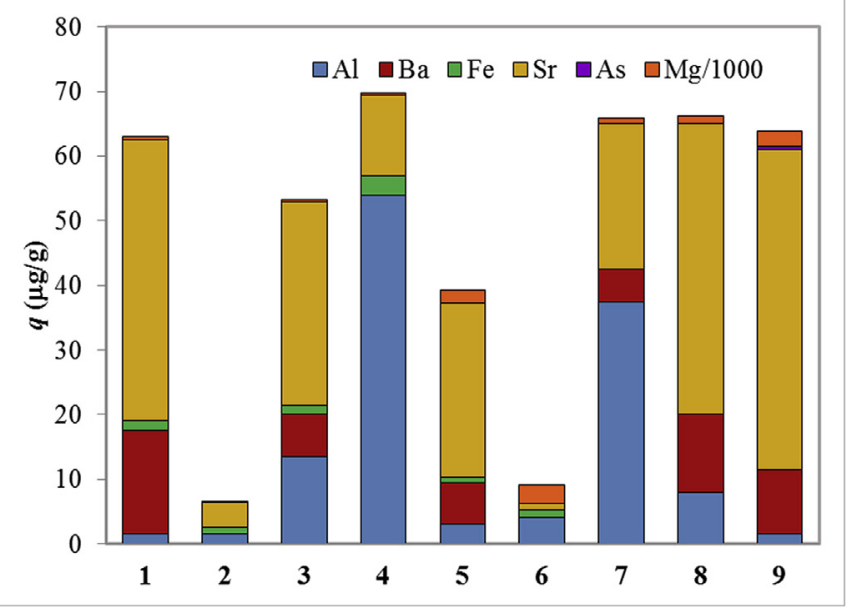

Fig. 3. Biosorption capacity $(q)$ of $\mathrm{MsAlg}$ for $\mathrm{Al}, \mathrm{Ba}, \mathrm{Fe}, \mathrm{Sr}, \mathrm{As}$ and $\mathrm{Mg}$ in the water of the lakes: 1-Bovan 2-Vlasina 3-Prvonek 4-Garaši 5-Ćelije 6-Vrutci 7-Sava 8-Gruža 9-Srebrno.
Therefore, the maximum biosorption capacity for $\mathrm{Al}(54 \mu \mathrm{g} / \mathrm{g})$ and for $\operatorname{Sr}(49.5 \mu \mathrm{g} / \mathrm{g})$ was reached in Garaši and Srebrno lake, respectively. Obtained biosorption capacity values for $\mathrm{Mg}$ in the studied lakes were in the range from 0.13 to $2.82 \mathrm{mg} / \mathrm{g}$ (Fig. 3).

Apart from that, it was observed that boron, calcium, potassium, sodium and manganese were released (increased concentrations after biosorption were measured) in all examined lake water samples. The release of barium was noticed in samples from Vlasina and Garaši lakes.

The biosorption of aluminium was in the range of $21-90 \%$; in five lakes it was higher than 50\% (Fig. S1, Supplementary material). In all lake water samples where barium was detected, it was biosorbed in the range of 52-77\% (Fig. S2, Supplementary material). The examined biosorbent has removed $25-55 \%$ of iron (Fig. S3, Supplementary material). Magnesium was biosorbed in the smallest percent (12-24\%) (Fig. S4, Supplementary material) More than $50 \%$ of strontium was removed by biosorption from six lake water samples (Fig. S5, Supplementary material), while $14.3 \%$ of arsenic was removed from Srebrno lake (the only sample where it was detected). The overall average efficiency of MsAlg in the removal of elements was in the order: $\mathrm{Al}>\mathrm{Ba}>\mathrm{Sr}>\mathrm{Fe}>\mathrm{Mg}$ (58.6, 51.7, 48.2, 23.9 and $17.7 \%$, respectively). The results point out that the applied biosorbent was efficient in respect to some of the detected elements.

Application $M$. spicatum as biosorbent meets all 4E requirements: i.e. it is easy to cut and collect (Engineering), does not need additional energy for drying (Energy), solves some potential ecological problems (Ecology) and it is low-cost (Economy).

Divalent cation $\left(\mathrm{Ca}^{2+}\right)$ interacts with blocks of acid residues from alginate, resulting in the formation of a 3D network, which is generally explained as "egg-box" model (Grant et al., 1973). After biosorption experiments, MsAlg beads could easily be separated from the lake water samples (by decantation). They didn't change the shape, size and colour during the experiments nor did the mixing rate affect them. Beads were solid and easy to manage. The strength of MsAlg beads can be explained by the formation of "egg-box" model not only with calcium from calcium chloride which was added during the immobilization process, but also with calcium from $M$. spicatum water weed. The increase in the amount of calcium in the studied water samples after biosorption can be explained by probable replacement of calcium from biosorbent and metal ions from the samples according to the "egg-box" model (Mata et al., 2009). Affinity of potentially toxic elements by alginate depends on the extent of guluronic acid and other uronic acids. Carboxyl groups from these acids would be mostly included in metal biosorption (Davis et al., 2004). As suggested in literature, bidentate complexes with one carboxyl group, and ionic bonds (as presented by the "egg-box" model with $\mathrm{Ca}^{2+}$ ) are two possible ways of bonding between carboxyl groups and $\mathrm{M}^{2+}$ cation (Mata et al., 2009). Zooms into single binding zone show these types of bonds (graphical abstract). It may be assumed that elements absorbed by MsAlg in this study undergo a similar pattern, although more complex studies are necessary in order to establish a possible mechanism. According to Datta et al. (2008), the order of alginate affinity towards divalent ions is:

$\mathrm{Pb}>\mathrm{Cu}>\mathrm{Cd}>\mathrm{Ba}>\mathrm{Sr}>\mathrm{Ca}>\mathrm{Co}, \mathrm{Ni}, \mathrm{Zn}>\mathrm{Mn}$.

In our study, calcium release and biosorption of magnesium caused a change in the total hardness (TH). Generally, an increase of TH in all studied samples was noticed (Fig. 4) and the extent of the changes was in the order: Vlasina $>$ Ćelije $>$ Prvonek $>$ Garaši $>$ Sava $>$ Gruža $>$ Bovan $>$ Srebrno $>$ Vrutci. Experimental data on contents of $\mathrm{Ca}, \mathrm{Mg}$ and $\mathrm{TH}$ in the examined water samples from lakes, before and after sorption, can be supported by literature (Mata et al., 2009; Datta et al., 2008). 


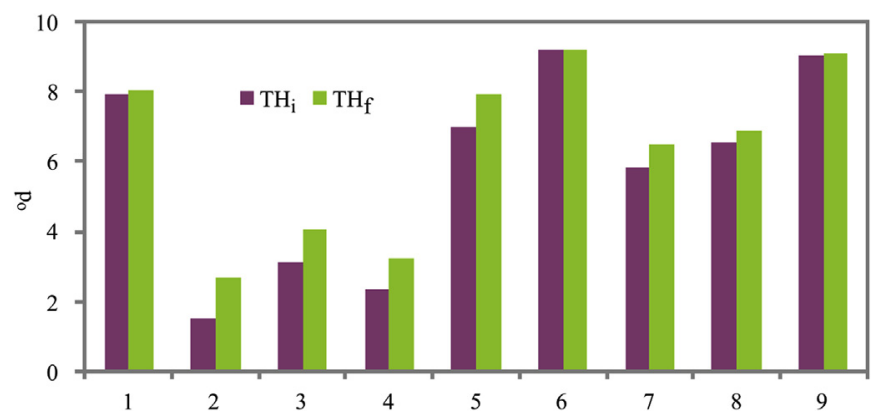

Fig. 4. Total hardness $\left({ }^{\circ} \mathrm{d}\right)$ : initial $\mathrm{TH}_{\mathrm{i}}$ and final $\mathrm{TH}_{\mathrm{f}}$ total hardness before and after biosorption in lake water samples: 1-Bovan 2-Vlasina 3-Prvonek 4-Garaši 5-Ćelije 6-Vrutci 7-Sava 8-Gruža 9-Srebrno.

\subsection{Descriptive analysis of elements in lake water samples}

The concentrations data set of eleven detected elements: Al, As, $\mathrm{B}, \mathrm{Ba}, \mathrm{Ca}, \mathrm{Fe}, \mathrm{K}, \mathrm{Mg}, \mathrm{Mn}, \mathrm{Na}$ and $\mathrm{Sr}$ as well as $\mathrm{pH}$ values for water samples of nine examined lakes were evaluated by PCA in order to determine the average concentrations of elements and perceive their variability. The experimental data and weight coefficients are shown in Table S4 (Supplementary material).

Water quality usually pertains to the structure of the water sample. Evaluations of water quality parameters are necessary for the improvement of water resources management. Water quality index (WQI) is a mathematical tool employed to convert considerable amounts of data on water quality (based on physical, chemical and biological measurements) into a single number that represents the water quality degree (Štambuk-Giljanović, 1999; Jakovljević, 2012).

In order to evaluate changes in water after sorption process with MsAlg, the water quality index (WQI), based on the contents of elements before and after biosorption and $\mathrm{pH}$ values (see Table S4, Supplementary material), was accounted for each lake. The obtained results are presented in Fig. 5. It should be underlined that the general trend was observed; the final WQI values $\left(W Q I_{f}\right)$, were higher than the initial $W Q I\left(W Q I_{i}\right)$ values for all studied lakes.

High correlations between observed elements were acquired using correlation analysis for detected elements in water samples. Correlation matrix of element concentrations, $\mathrm{pH}$ and WQI values in examined water samples is presented in Table 1. Barium is positively correlated to strontium content, statistically significant at $\mathrm{p}<0.01$ level. Iron is negatively correlated to $\mathrm{B}, \mathrm{K}$ and Na content, statistically significant at $\mathrm{p}<0.01$ level, and also negatively correlated to $\mathrm{pH}$ value, statistically significant at $\mathrm{p}<0.01$ level.

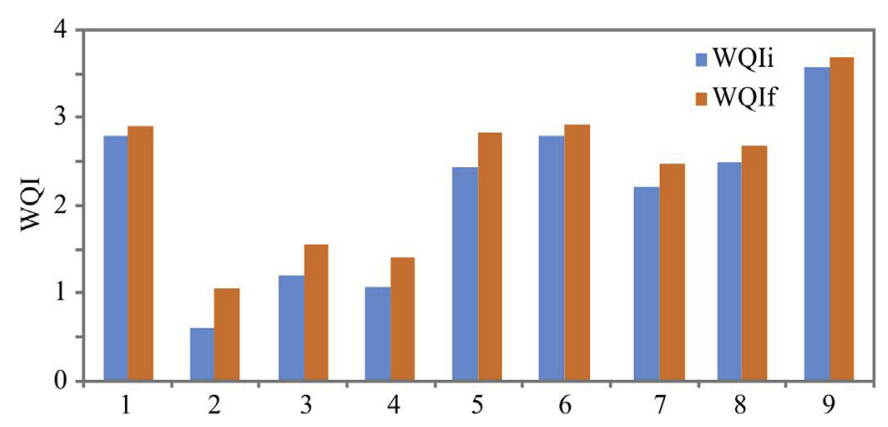

Fig. 5. WQI values of studied water samples from lakes: 1-Bovan 2-Vlasina 3-Prvonek 4-Garaši 5-Ćelije 6-Vrutci 7-Sava 8-Gruža 9-Srebrno; before and after biosorption by MsAlg evaluated by experimental results.
Magnesium is positively correlated to B content and WQI value, statistically significant at $\mathrm{p}<0.01$ level, while it is also positively correlated to As content and $\mathrm{pH}$ value, statistically significant at $\mathrm{p}<0.05$ level. Calcium is positively correlated to B and Mn content, statistically significant at $\mathrm{p}<0.01$ level, while it is also positively correlated to $\mathrm{K}$ and $\mathrm{Na}$ content and $\mathrm{pH}$ value, statistically significant at $\mathrm{p}<0.05$ level. Boron is positively correlated to $\mathrm{Na}$ and As content, $\mathrm{pH}$ and $\mathrm{WQI}$ value, statistically significant at $\mathrm{p}<0.01$ level, while it is also positively correlated to K content, statistically significant at $\mathrm{p}<0.05$ level. Potassium is positively correlated to Na content, statistically significant at $\mathrm{p}<0.01$ level, and also positively correlated to As content and $\mathrm{pH}$ value, statistically significant at $\mathrm{p}<0.05$ level. Sodium is positively correlated to As content, statistically significant at $\mathrm{p}<0.01$ level, while As content and $\mathrm{pH}$ value are positively correlated to WQI value, statistically significant at $\mathrm{p}<0.05$ level.

\subsection{Cluster analysis}

Fig. 6 shows the dendrogram of CA for the tested lake water samples. The complete linkage algorithm and City block (Manhat$\tan$ ) distances were used as the measure of proximity between the samples. City block distances (shown on abscissa axis) are measured as the average difference across dimensions of the tested lake water samples.

The resulting dendrogram showed three main clusters, the first cluster contained the samples from lakes Bovan, Sava and Gruža, as well as the sample from lake Ćelije (after biosorption). These samples contained a moderate amount of elements, according to experimental results. The second cluster comprised the samples from Vrutci and Srebrno lakes, as well as the sample taken from lake Ćelije. According to CA, the quality of water sample taken from Ćelije lake increased enough for the transfer to the first cluster, after biosorption. The third cluster contained the samples taken from Vlasina, Pronek and Garaši, which was characterised by the increased amount of $\mathrm{Fe}$ and $\mathrm{Al}$, compared to all other samples.

\subsection{Principal Component Analysis (PCA)}

Principal component investigation was performed to examine the relationships between environmental impacts and trace element concentrations in the observed water samples. The rotation of the obtained principal components was refined by the Varimax method and Kaiser Normalization. PCA analysis of element composition found in the water samples demonstrated that the first three principal components explained $73.09 \%$ of the total variance in the original data, Fig. 7. The first principal component (PC1) contributed $45.73 \%$, the second component (PC2) 14.96\%, and the third component (PC3) explained $12.40 \%$ of the total variance. The calculated first three Eigenvalues were: 5.95, 1.94 and 1.61, respectively. By assessing the PCA graph, the Fe content (which contributed 9.1\% of the total variance, based on correlations) gained the most intensive positive score for the first principal component evaluation, while the concentration of $\mathrm{Mg}$ (9.2\%), $\mathrm{Ca}(8.7), \mathrm{B}(14.8 \%), \mathrm{K}(8.0 \%), \mathrm{Na}$ (10.7\%) and $\mathrm{As}$ (7.7\%), and the values of $\mathrm{pH}(9.0 \%)$ and WQI $(9.2 \%)$ demonstrated negative score values of the first principal component (Fig. 5). The contents of $\mathrm{Al}$ (which yielded $29.3 \%$ of the total variance, based on correlations), $\mathrm{Ba}(34.4 \%)$ and $\mathrm{Sr}(21.5 \%)$ showed positive influence on the second principal component evaluation, whereas the concentration of Mn (23.6\%) showed negative influence on the second principal component. The contents of $\mathrm{K}$ (which explained $21.3 \%$ of the total variance, based on correlations) and $\mathrm{Na}(13.4 \%)$ showed positive influence on the third principal component evaluation, while the content of $\mathrm{Mg}$ (24.7\%) and WQI value (24.5\%) showed negative influence on the third principal component. 
Table 1

Correlation matrix of element contents, $\mathrm{pH}$ and WQI in the water samples from the studied lakes.

\begin{tabular}{|c|c|c|c|c|c|c|c|c|c|c|c|c|}
\hline & $\mathrm{Ba}$ & $\mathrm{Fe}$ & $\mathrm{Mg}$ & $\mathrm{Sr}$ & $\mathrm{Ca}$ & B & K & Mn & $\mathrm{Na}$ & As & $\mathrm{pH}$ & WQI \\
\hline $\mathrm{Al}$ & 0.033 & 0.103 & -0.245 & -0.027 & -0.351 & -0.229 & -0.263 & $-0.457^{c}$ & -0.105 & -0.197 & -0.056 & -0.235 \\
\hline $\mathrm{Ba}$ & & -0.074 & 0.175 & $0.898^{\mathrm{a}}$ & 0.225 & 0.149 & 0.261 & -0.226 & 0.183 & 0.087 & $0.427^{c}$ & 0.183 \\
\hline $\mathrm{Fe}$ & & & -0.364 & -0.265 & $-0.436^{c}$ & $-0.682^{\mathrm{a}}$ & $-0.625^{\mathrm{a}}$ & $-0.443^{c}$ & $-0.711^{\mathrm{a}}$ & $-0.446^{\mathrm{c}}$ & $-0.592^{\mathrm{b}}$ & -0.364 \\
\hline $\mathrm{Mg}$ & & & & 0.385 & $0.411^{c}$ & $0.824^{\mathrm{a}}$ & 0.188 & 0.218 & 0.312 & $0.472^{\mathrm{b}}$ & $0.567^{b}$ & $1.000^{\mathrm{a}}$ \\
\hline $\mathrm{Sr}$ & & & & & 0.381 & 0.397 & 0.473 & 0.032 & $0.448^{c}$ & 0.379 & $0.436^{c}$ & 0.392 \\
\hline $\mathrm{Ca}$ & & & & & & $0.698^{\mathrm{a}}$ & $0.476^{\mathrm{b}}$ & $0.601^{\mathrm{a}}$ & $0.508^{\mathrm{b}}$ & 0.191 & $0.559^{b}$ & $0.410^{c}$ \\
\hline B & & & & & & & $0.507^{\mathrm{b}}$ & $0.423^{c}$ & $0.701^{\mathrm{a}}$ & $0.622^{\mathrm{a}}$ & $0.710^{\mathrm{a}}$ & $0.824^{\mathrm{a}}$ \\
\hline K & & & & & & & & 0.374 & $0.819^{a}$ & $0.488^{\mathrm{b}}$ & 0.322 & 0.189 \\
\hline Mn & & & & & & & & & 0.332 & 0.162 & 0.074 & 0.213 \\
\hline $\mathrm{Na}$ & & & & & & & & & & $0.789^{\mathrm{a}}$ & $0.453^{c}$ & 0.314 \\
\hline As & & & & & & & & & & & 0.319 & $0.472^{\mathrm{b}}$ \\
\hline $\mathrm{pH}$ & & & & & & & & & & & & $0.570^{\mathrm{b}}$ \\
\hline
\end{tabular}

a Correlation statistically significant at $\mathrm{p}<0.01$ level.

${ }^{b}$ Correlation statistically significant at $\mathrm{p}<0.05$ level.

c Correlation statistically significant at $\mathrm{p}<0.10$ level. Unmarked correlations are not statistically significant.

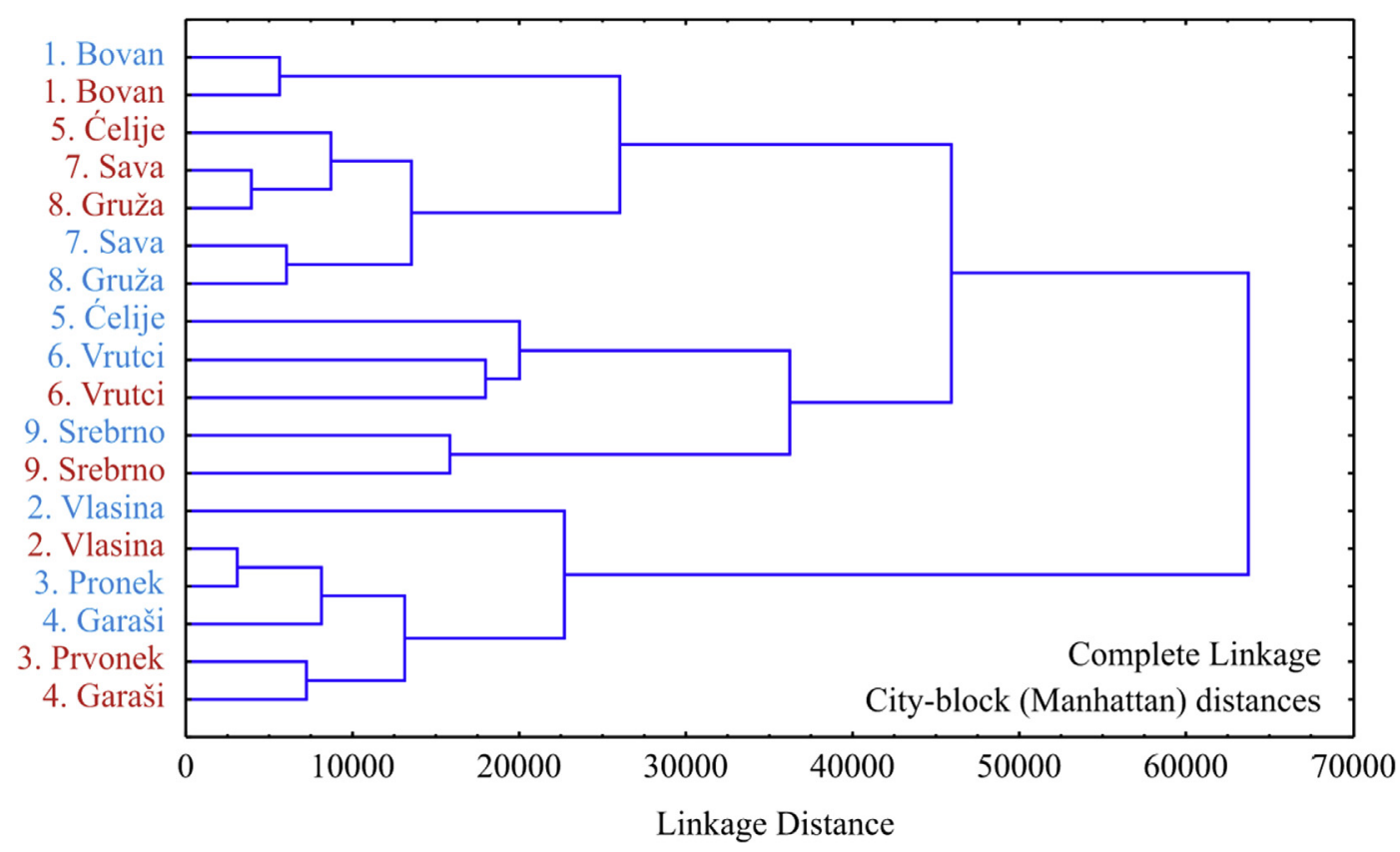

Fig. 6. Dendogram of elements in lake water samples and their locations: 1-Bovan 2-Vlasina 3-Prvonek 4-Garaši 5-Ćelije 6-Vrutci 7-Sava 8-Gruža 9-Srebrno.

As can be seen, there is good partitioning of the nine lakes according to observed elements concentrations, $\mathrm{pH}$ and WQI. The initial values of variables are presented by blue dots, while the final values of the observed variables are coloured as red dots in Fig. 7. The influence of different parameters that depicts the observed lake samples could be assessed from the scatter plot (Fig. 7) in which the explored sites with higher Fe content are located at the right side of the PCA scheme (lakes Vlasina, Prvonek, and Garaši - 2, 3 and 4, respectively), site with expanded $\mathrm{Mg}$, As, $\mathrm{Na}, \mathrm{B}, \mathrm{K}$ and Ca content, $\mathrm{pH}$ and WQI values (lake Srebrno - 9) is situated at the left side of the PCA diagram. The variations in $\mathrm{Fe}, \mathrm{Mg}, \mathrm{As}, \mathrm{Na}, \mathrm{B}, \mathrm{K}$ and $\mathrm{Ca}$ concentration, $\mathrm{pH}$ and $\mathrm{WQI}$ values, after the biosorption with manure can be more effortlessly spotted for water of Vlasina lake, while the higher changes in $\mathrm{Al}$ and Mn content are observed for the lakes Prvonek and Garaši. The highest changes in $\mathrm{Sr}$, Ba and Mn content are seen in the water samples from lakes Bovan, Ćelije, Vrutci, Sava, Gruža and Srebrno.

The correlation matrix of sorption properties of biosorbent MsAlg applied for biosorption process in lake water samples is introduced in Table 2. It can be noticed that TH was highly positively correlated with initial $\mathrm{pH}$ and biosorption process, statistically significant at $\mathrm{p}<0.01$ level. The descriptive statistics of sorption characteristics of MsAlg is depicted in Table S5 (Supplementary material).

For visual interpretation of the obtained data trends and for the appropriate discriminating efficiency of the used descriptors a scatter plot of samples using the first two principal components (PCs) from PCA of the data matrix is obtained (Fig. 8).

\section{Conclusions}

Preliminary assessment of the properties of immobilized M. spicatum with alginate-MsAlg in water samples from nine freshwater lakes was done.

- For the first time, the beads of aquatic weed and alginate (Ms:Alginate 2:1 ratio) were applied for biosorption in a real system. The experiment showed that MsAlg absorbed 

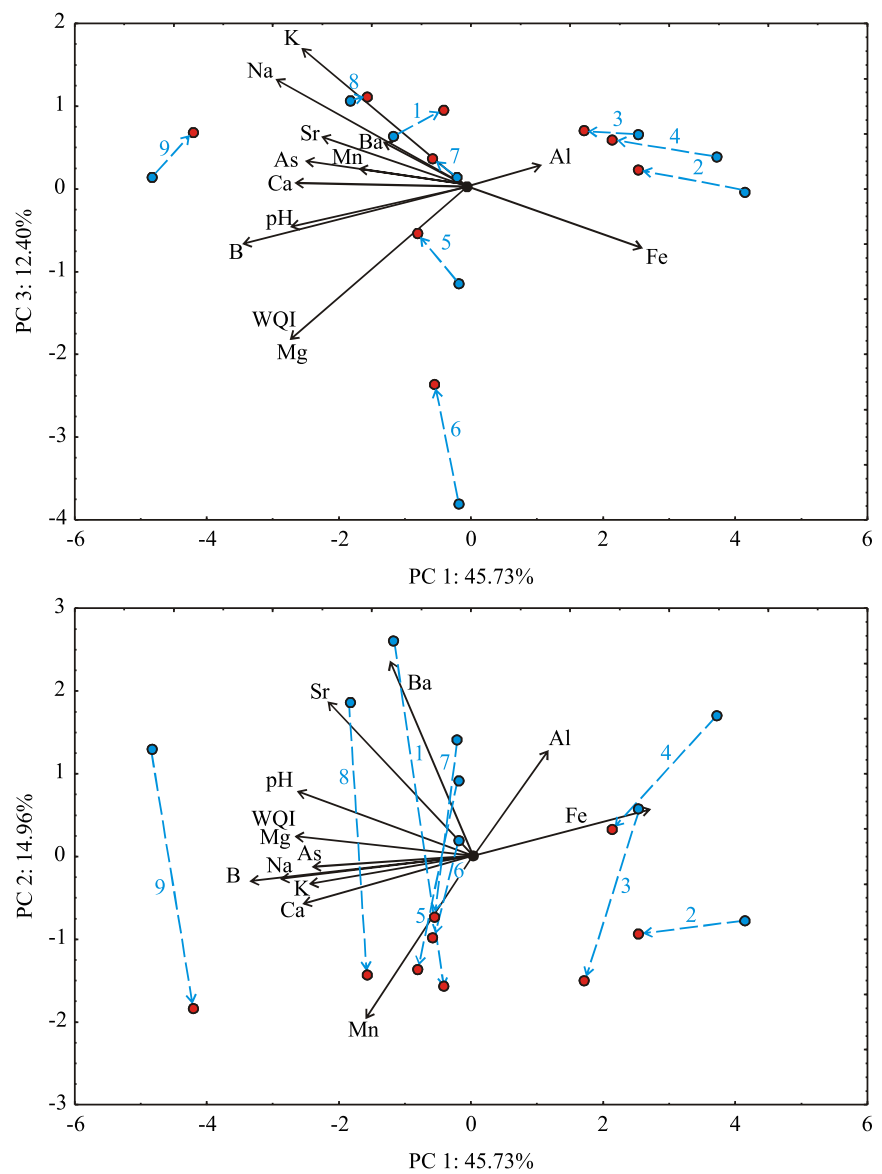

Fig. 7. Biplot of correlated elements in lake water samples and their locations: 1-Bovan 2-Vlasina 3-Prvonek 4-Garaši 5-Ćelije 6-Vrutci 7-Sava 8-Gruža 9-Srebrno.

Table 2

Correlation matrix of sorption characteristics of MsAlg applied for biosorption in lake water samples.

\begin{tabular}{llll}
\hline & Biosorption & Leakage & TH \\
\hline Initial pH & 0.528 & 0.394 & $0.861^{\mathrm{a}}$ \\
Biosorption & & -0.497 & $0.830^{\mathrm{a}}$ \\
Leakage & & & -0.025 \\
\hline
\end{tabular}

${ }^{a}$ Correlation statistically significant at $\mathrm{p}<0.01$ level; Unmarked correlations are not statistically significant.

aluminium, magnesium and strontium in the water samples from all studied lakes; barium and iron in the water samples from six lakes.

- The average efficacy of MsAlg biosorption ranged from $17.7 \%$ for $\mathrm{Mg}$ to $58.6 \%$ for $\mathrm{Al}$.

- The highest content of Al was observed in water samples from lakes Garaši and Prvonek. After the biosorption with MsAlg its content was decreased. In addition, content of As was reduced in the water sample from Srebrno lake.

- According to the results of the cluster analysis, the quality of water after biosorption process increased for the sample from lake Ćelije and the purified sample was displaced to a group with better water quality.

- The most noticeable variations in the studied parameters were observed for the sample taken from the lake Vlasina, as shown on PCA diagram, while the highest changes in $\mathrm{Al}$ and Mn content after biosorption were observed for samples from lakes Prvonek

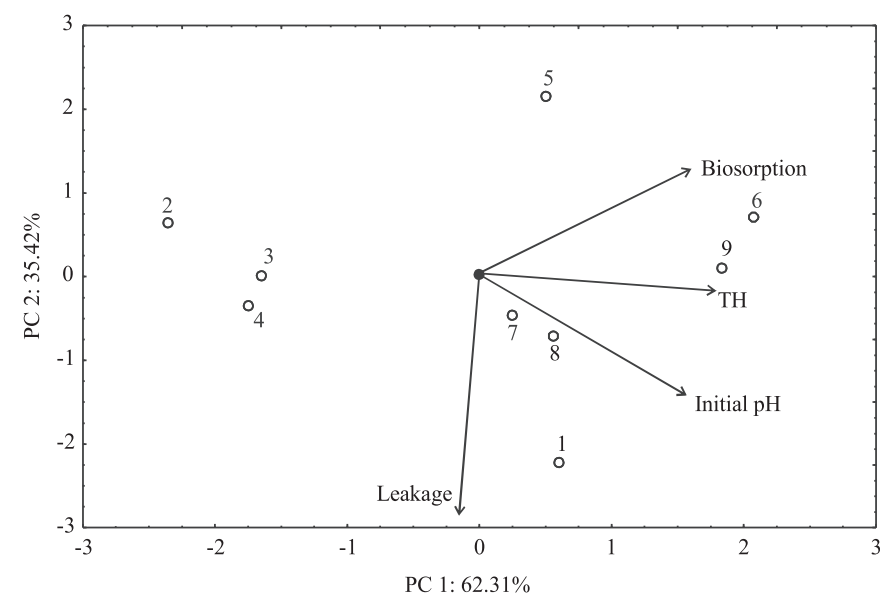

Fig. 8. Biplot of sorption characteristics of MsAlg applied for biosorption in water samples from lakes: 1-Bovan 2-Vlasina 3-Prvonek 4-Garaši 5-Ćelije 6-Vrutci 7-Sava 8-Gruža 9-Srebrno.

and Garaši. The most intensive changes in Sr, Ba and Mn content were observed in the samples from lakes Bovan, Ćelije, Vrutci, Sava, Gruža and Srebrno.

It can be noticed that $\mathrm{TH}$ was highly positively correlated to initial $\mathrm{pH}$ and biosorption process. The presented data contribute to a more complete evaluation of MsAlg beads' biosorption characteristics. Additional experiments are required for its potential use as a biofilter (in the treatment or pre-treatment of drinking water with the aim to gain improved quality).

\section{Acknowledgment}

Authors acknowledge the Ministry of Education, Science and Technological Development of the Republic of Serbia for financial support (Grant Nos. TR 31003, III 46009 and TR 31055). Jelena Milojković is grateful to the public company "Ada Ciganlija” (Belgrade, Serbia) for providing samples of aquatic weed M. spicatum. Authors also thank D. Popović-Beogračić for the design and processing of the graphical abstract.

\section{Appendix A. Supplementary data}

Supplementary data related to this article can be found at https://doi.org/10.1016/j.watres.2018.05.014.

\section{Conflicts of interest}

The authors report no declarations of interest.

\section{References}

Aiken, S.G., Newroth, R., Wiles, I., Control, H., 1979. The biology of Canadian weeds: 34. Myriophyllum spicatum. Can. J. Plant Sci. 59, 201-215.

Aquion [WWW Document], 2016. URL www.aqion.de/site/140.

Anonymous, 1986. Mala Prosvetina Enciklopedija, third ed. Prosveta, Beograd (In Serbian).

Anonymous, 2001. Water Management Base of the Republic of Serbia, Institute for Water Management "Jaroslav Černi". Ministry of Agriculture, Forestry and Water Management, Belgrade (In Serbian). http://www.srbijavode.rs/Data Files/vodoprivredna_osnova_republike_srbije.pdf.

Azizian, M., Boano, F., Detwiler, R.L., Rippy, M.A., 2017. Ambient groundwater flow diminishes nitrate processing in the hyporheic zone of streams. Water Resour Res. 3941-3967. https://doi.org/10.1002/2016WR020048.Received.

Bates, A.L., Burns, E.R., Webb, D.H., 1985. Eurasian watermilfoil (Myriophyllum spicaturn L.) in the Tennessee valley: an update on biology and control. In: Anderson, L.W.J. (Ed.), Proceedings, First International Symposium on 
Watermilfoil (Myriophyllum spicatum) and Related Haloragaceae Species. Aquatic Plant Management Society, Washington D.C., pp. 104-115

Bolotov, I.N., Auda, Y., Bespalaya, Y.V., 2015. Trace element composition of freshwater pearl mussels Margaritifera spp. across Eurasia: testing the effect of species and geographic location. Chem. Geol. 402, 125-139. https://doi.org/ 10.1016/i.chemgeo.2015.03.006.

Chang, N., Chen, H.W., Ning, S.K., 2001. Identification of river water quality using the Fuzzy Synthetic Evaluation approach. J. Environ. Manag. 63, 293-305. https:// doi.org/10.1006/jema.2001.0483.

Cheng, J., Yin, W., Chang, Z., Lundholm, N., Jiang, Z., 2017. Biosorption capacity and kinetics of cadmium ( II ) on live and dead Chlorella vulgaris. J. Appl. Phycol. 29, 211-221. https://doi.org/10.1007/s10811-016-0916-2.

Couch, R. Nelson, E. 1985. Myriophyllum spicatum in North America. In: Anderson, L.W.J. (Ed.), Proceedings,First International Symposium on Watermilfoil and Related Halor-agaceae Species. Aquatic Plant Management Society, Vicksburg, MS, Vancouver, BC, pp. 43-45.

Datta, S., Janes, M.E., Xue, Q.G., Losso, J., La Peyre, J.F., 2008. Control of Listeria monocytogenes and Salmonella anatum on the surface of smoked salmon coated with calcium alginate coating containing oyster. J. Food Sci. 73, 67-71. https:// doi.org/10.1111/j.1750-3841.2007.00633.x.

Davis, T.A., Ramirez, M., Mucci, A., Larsen, B., 2004. Extraction, isolation and cadmium binding of alginate from Sargassum spp. J. Appl. Phycol. 196, 275-284.

Dibdiakova, J., Wang, L., Li, H., 2015. Characterization of ashes from Pinus sylvestris forest biomass. Energy Procedia 75, 186-191. https://doi.org/10.1016/ j.egypro.2015.07.289.

EPA Environmental Protection Agency, Ireland, 2001. Parameters of Water Quality: Interpretation and Standards. Environmental Protection Agency, Ireland, Wexford.

Grant, G.T., Morris, E.R., Rees, D.A., Smith, P.J.C., Thom, D., 1973. Biological interactions between polysaccharides and divalent cations: the egg-box model FEBS Lett. 32, 195-198.

ISO - International Organization for Standardization, 2014. ISO 5667-14:2014 Water Quality - Sampling - Part 14: Guidance on Quality Assurance and Quality Control of Environmental Water Sampling and Handling.

Jakovljević, D., 2012. Serbian and Canadian water quality index of Danube river in Serbia in 2010. J. Geogr. Inst. "Jovan Cvijić" 62, 1-18. https://doi.org/10.2298 IJGI1203001J.

Kostić, A.Ž., Pantelić, Đ., Kaluđerović, L.M., Jonaš, J.P., Dojčinović, B.P., PopovićDjordjević, J.B., 2016. Physicochemical properties of waters in Southern Banat (Serbia); potential leaching of some trace elements from ground and human health risk. Expo. Heal. 8, 227-238. https://doi.org/10.1007/s12403-016-0197-7.

Kratochvil, D., Volesky, B., 1998. Advances in the biosorption of heavy metals. Tibtech 16, 291-300. https://doi.org/10.1016/S0167-7799(98)01218-9.

Lehtonen, K., Turja, R., Budzinski, H., Devier, M.-H., 2016. An integrated chemicalbiological study using caged mussels ( Mytilus trossulus ) along a pollution gradient in the Archipelago Sea. Mar. Environ. Res. 119, 207-221. https:// doi.org/10.1016/j.marenvres.2016.06.003.

Mata, Y.N., Blázquez, M.L., Ballester, A., González, F., Mũnoz, J.A., 2009. Biosorption of cadmium, lead and copper with calcium alginate xerogels and immobilized Fucus vesiculosus. J. Hazard Mater. 163, 555-562. https://doi.org/10.1016 j.jhazmat.2008.07.015.

Mezzelani, M., Gorbi, S., Fattorini, D., Errico, G., Benedetti, M., Milan, M., 2016. Transcriptional and cellular effects of Non-Steroidal Anti-Inflammatory Drugs (NSAIDs) in experimentally exposed mussels, Mytilus galloprovincialis. Aquat. Toxicol. 180, 306-319. https://doi.org/10.1016/j.aquatox.2016.10.006.

Milojković, J.V., Mihajlović, M.L., Stojanović, M.D., Lopičić, Z.R., Petrović, M.S. Soštarić, T.D., Ristić, M.Đ., 2014. Pb(II) removal from aqueous solution by Myriophyllum spicatum and its compost: equilibrium, kinetic and thermodynamic study. J. Chem. Technol. Biotechnol. 89, 662-670. https://doi.org/10.1002/ jctb.4184.

Milojković, J., Stojanović, M., Mihajlović, M., Lopičić, Z., 2016a. Removal of Pb ( II ) using alginate - immobilized Myriophyllum spicatum beads. Eur. J. Sustain. Dev. 5, 457-463. https://doi.org/10.14207/ejsd.2016.v5n4p457.

Milojković, J., Pezo, L., Stojanović, M., Mihajlović, M., Lopičić, Z., Petrović, J. Stanojević, M., Kragović, M., 2016b. Selected heavy metal biosorption by compost of Myriophyllum spicatum-A chemometric approach. Ecol. Eng. 93, 112-119. https://doi.org/10.1016/j.ecoleng.2016.05.012.

Mohan, S.V., Nikhil, G.N., Chiranjeevi, P., Reddy, C.N., Rohit, M.V., Kumar, A.N., 2016
Bioresource Technology Waste biorefinery models towards sustainable circular bioeconomy: critical review and future perspectives. Bioresour. Technol. https://doi.org/10.1016/j.biortech.2016.03.130.

Official Gazette of Serbia, 2014. Regulation on Limit Values of Pollutants in Surface and Ground Waters and Sediments and Deadlines for Their Achievement. No. 24/2014 (In Serbian).

Olenycz, M., Sokolowski, A., Niewińska, A., Wołowicz, M., Namieśnik, J., Hummel, H., Jansen, J., 2015. ScienceDirect Comparison of PCBs and PAHs levels in European coastal waters using mussels from the Mytilus edulis complex as biomonitors. Oceanologia 57, 196-211. https://doi.org/10.1016/j.oceano.2014.12.001.

Pain-Devin, S., Cossu-Leguille, C., Geffard, A., Giambérini, L., Jouenne, T., Minguez, L., Naudinc, B., Parant, M., Rodiusa, F., Rousselle, P., Tarnowska, K., DaguinThiébaut, C., Viard, F., Devin, S., 2014. Towards a better understanding of biomarker response in field survey: a case study in eight populations of zebra mussels. Aquat. Toxicol. 155, 52-61. https://doi.org/10.1016/ j.aquatox.2014.06.008.

Robinson, C.D., Webster, L., Martínez-Gomez, Concepcion Burgeot, T., Gubbins, M.J., Thain, J.E., Vethaak, A.D., Mcintosh, A.D., Hylland, K., 2017. Assessment of contaminant concentrations in sediments, fish and mussels sampled from the North Atlantic and European regional seas within the ICON project. Mar. Environ. Res. 124, 21-31. https://doi.org/10.1016/j.marenvres.2016.04.005.

Şener, Ş., Şener, E., Davraz, A., 2017. Evaluation of water quality using water quality index ( WQI ) method and GIS in Aksu River (SW-Turkey ). Sci. Total Environ. J. 584-585, 131-144. https://doi.org/10.1016/j.scitotenv.2017.01.102.

Štambuk-Giljanović, N., 1999. Water quality evaluation by index in Dalmatia. Water Res. 33, 3423-3440. https://doi.org/10.1016/S0043-1354(99)00063-9.

Stevanović, B.M., Janković, M., 2001. Ekologija Biljaka Sa Osnovama Fiziološke Ekologije Biljaka. NNK international, Belgrade (In Serbian).

Tan, F., Lu, Z., 2015. Study on the interaction and relation of society, economy and environment based on PCA - VAR model: as a case study of the Bohai Rim region, China. Ecol. Indic. 48, 31-40. https://doi.org/10.1016/ j.ecolind.2014.07.036.

Taqieddin, E., Amiji, M., 2004. Enzyme immobilization in novel alginate - chitosan core-shell microcapsules. Biomaterials 25, 1937-1945. https://doi.org/10.1016/ j.biomaterials. 2003. 08. 034

Touahri, H.G., Boutiba, Z., Benguedda, W., Shaposhnikov, S., 2016. Active biomonitoring of mussels Mytilus galloprovincialis with integrated use of micronucleus assay and physiological indices to assess harbor pollution. Mar. Pollut. Bull. 110, 52-64. https://doi.org/10.1016/j.marpolbul.2016.06.029.

U.S. Environmental Protection Agency. Method 200.7, 1994. Determination of Metals and Trace Elements in Water and Wastes by Inductively Coupled Plasma-atomic Emission Spectrometry. Revision 4.4. https://www.epa.gov/ sites/production/files/2015-08/documents/method_200-7_rev_4-4_1994.pdf. (Accessed 1 August 2017)

US EPA Environmental Protection Agency, 2016a. National Primary Drinking Water Regulations. https://www.epa.gov/sites/production/files/2016-06/documents/ npwdr_complete_table.pdf.

US EPA Environmental Protection Agency, 2016b. Secondary Drinking Water Standards. https://www.epa.gov/dwstandardsregulations/secondary-drinkingwater-standards-guidance-nuisance-chemicals\#table.

Volesky, B., 2007. Biosorption and me. Water Res. 41, 4017-4029. https://doi.org/ 10.1016/j.watres.2007.05.062.

WHO World Health Organization, 2011. Guidelines for Drinking-water Quality, fourth. ed. Geneva. http://apps.who.int/iris/bitstream/10665/44584/1/ 9789241548151 eng.pdf.

WHO World Health Organization, 2008. In: World Health Organization (Ed.), Guidelines for Drinking-water Quality Incorporating the First and Second Addenda, third ed. Geneva. http://www.who.int/water_sanitation_health/dwq/ fulltext.pdf

Yan, G., Viraraghavan, T., 2001. Heavy metal removal in a biosorption column by immobilized $M$. rouxii biomass. Bioresour. Technol. 78, 243-249. https:// doi.org/10.1016/S0960-8524(01)00020-7.

Zhaoyong, Z., Abuduwaili, J., Fengqing, J., 2015. Heavy metal contamination, sources, and pollution assessment of surface water in the Tianshan Mountains of China, 187, 33. https://doi.org/10.1007/s10661-014-4191-X.

Zhou, Z., Li, G., Li, Y., 2010. Immobilization of Saccharomyces cerevisiae alcohol dehydrogenase on hybrid alginate - chitosan beads. Int. J. Biol. Macromol. 47, 21-26. https://doi.org/10.1016/j.ijbiomac.2010.04.001. 